\title{
STRATEGI KOMUNIKASI POLITIK \\ DALAM PEMILIHAN KEPALA DAERAH \\ KABUPATEN KEPAHIANG \\ 2015
}

\section{Amansyah*}

\begin{abstract}
The election of the District Head and Deputy Regent of Kepahiang in 2015 is a decisive democratic process for 5 years. With the election, electing executive officials, namely the Regent and his Deputy in accordance with the rules of the General Election Commission (KPU) No. 7 of 2006. The dynamics of local politics ahead of The election of leader of Kepahiang was increasingly lively approaching election day. The local pair election appeared on the surface, marked by various kinds of political maneuvers carried out by each pair of the election in Kepahiang held on December 9, 2015. The pair of candidates in the 2015 in Kepahiang regency included: the first sequence number was the first pair, Ir. Firdaus Djalani and Bahruddin. Secondly, Dr. Ir. Hidayatullah Sjahid, MM and Netti Herawati, S. Sos and third Bambang Sugianto, SH, M. Hum and Arbi, S.IP. The nomination of the pair Hidayatullah Sjahid and Netti Herawati was carried out by 3 political parties who had seats in the House of Representative (DPRD) of Kepahiang regency. The parties that carry the pair Hidayatullah Sjahid and Netti Herawati include: Nasdem Party, Hanura Party, Gerindra Party. The nomination has been supported by parliamentary parties and non-parliamentary parties in general through three important stages, namely, first, the selection of candidates. Second, filtering and selection that has been netted. Third, the determination of candidates. Political Communication Strategy of Hidayatullah Sjahid and Netti Herawati pairs. Previously, he was also the acting officer (PLT) of the regent in Kepahiang. As a candidate who has held office, Hidayatullah Sjahid's position has a number of advantages over other candidates in the 2015 Kepahiang Regional Election. Besides having political investment in the Kepahiang regional election, Hidayatulah Sjahid as a candidate who has benefited from cooperating with Netti Herawati, who has high popularity in people's eyes.
\end{abstract}

Keywords: Political Communication Strategy, General Election

\section{PENDAHULUAN}

Perubahan dalam perpolitikan Indonesia sejak jatuhnya rezim Soeharto telah memberikan ruang demokrasi yang sesungguhnya. Hal ini ditandai dengan lahirnya era Reformasi, di mana Indonesia menjadi negara yang kian menghargai hakhak warga negaranya terutama dalam menentukan pemimpinnya. Pemerintahan yang sebelumnya sentralistik diubah menjadi desentralistik dalam artian pemerintahan pusat memberikan wewenang kepada daerahnya masingmasing untuk memilih kepala daerah dan wakilnya. Selain itu juga memberikan ruang demokrasi politik lokal menjadi terbuka dan bebas dalam menentukan pembangunan di daerahnya masingmasing.

Ruang demokrasi itu terletak pada implementasi otonomi daerah diatur dalam UU No. 32 Tahun 2004 yang di dalam penjelasan umumnya diterangkan sebagai berikut: pembentukan daerah pada 
dasarnya dimaksudkan untuk meningkatkan pelayanan publik guna mempercepat terwujudnya kesejahteraan masyarakat, di samping sebagai sarana pendidikan politik di tingkat lokal. Maka pembentukan daerah harus mempertimbangkan berbagai faktor seperti kemampuan ekonomi, potensi daerah, luas wilayah, kependudukan, dan pertimbangan dari aspek sosial politik, sosial budaya, pertahanan, dan keamanan serta pertimbangan dan syarat lain yang memungkinkan daerah itu dapat menyelenggarakan dan mewujudkan tujuannya ${ }^{1}$.

Oleh sebab itu, otonomi daerah yang dijalankan selain bersifat nyata dan luas, tetap harus dilaksanakan secara bertanggung jawab. Maksudnya otonomi daerah harus dipahami sebagai perwujudan pertanggungjawaban konsekuensi pemberian hak dan kewenangan kepada daerah dalam wujud tugas dan kewajiban yang harus dilaksanakan daerah. Ide dasar dari pemberian otonomi kepada daerah sejatinya adalah untuk; pertama, meningkatkan pelayanan dan kesejahteraan masyarakat yang semakin baik; kedua, memelihara hubungan yang serasi antara pusat dan daerah serta antardaerah dalam rangka menjaga keutuhan Negara Kesatuan Republik Indonesia (NKRI); ketiga, mengembangkan kehidupan demokrasi, keadilan dan pemerataan.

Dalam rangka menjalankan tugas dan kewajiban tersebut, esensi mendasar dalam kebijakan pelaksanaan otonomi daerah adalah pemberian kewenangan yang ditetapkan batasan kewenangan yang dimiliki daerah untuk mengatur dan mengurus rumah tangganya sendiri. Adanya pemberian kewenangan ini tentu merupakan esensi dasar dalam pelaksanaan otonomi daerah di mana daerah mempunyai cukup keleluasaan gerak dalam menggunakan potensinya, baik yang berasal dari daerahnya sendiri maupun dari pemberian pemerintah pusat sesuai dengan kebutuhan daerah dan kesejahteraan masyarakatnya ${ }^{3}$.

Di samping itu, perubahan sangat signifikan terhadap perkembangan demokrasi di daerah, sesuai dengan tuntutan reformasi adalah pemilihan kepala daerah dan wakil kepala daerah secara langsung, dan tidak lagi dilakukan melalui pemilihan di DPRD. Pemilihan kepala daerah dan wakilnya secara langsung ini merupakan konsekuensi perubahan tatanan kenegaraan kita akibat amandemen UUD 1945. Undang-undang baru ini pada dasarnya mengatur mengenai penyelenggaraan pemerintah daerah dalam rangka melaksanakan kebijakan desentralisasi ${ }^{4}$. 
Dalam konteks itu, kepala daerah yang terpilih nantinya bisa menjalani asas desentralisasi, karena ia adalah pejabat yang dekat dengan masyarakat lokal dan diharapkan lebih peka terhadap segala permasalahan daerahnya masing-masing, karena lebih mengerti segala yang dibutuhkan oleh masyarakatnya. Oleh karena itu, otonomi daerah mempunyai tanggung jawab terhadap rakyat secara langsung yang dibebankan kepada kepala daerah terpilih melalui pilkada langsung.

\section{KAJIAN TEORI}

\section{A. Sistem Pemilihan Kepala Daerah}

Menurut Ramlan Surbakti, ada dua alasan mengapa kepala daerah dan wakil kepala daerah dipilih secara langsung. Pertama, agar lebih konsisten dengan sistem pemerintahan presidensial. Sistem pemerintahan presidensial antara lain ditandai oleh pemilihan kepala pemerintahan secara langsung oleh rakyat. Karena itu sebagaimana pada tingkat nasional presiden sebagai kepala pemerintahan dipilih langsung oleh rakyat melalui pemilihan umum, maka untuk kepala daerah otonom juga dipilih secara langsung oleh rakyat melalui pemilihan umum.Dengan memilih secara langsung siapa yang memimpin suatu daerah, rakyat yang berhak memilih dapat menentukan kepala daerah macam apakah yang akanmemimpin daerahnya, dan dapat menentukan pola dan arah kebijakan macam apakah yang akan dibuat dan dilaksanakan untuk kesejahteraan daerah. Kedua, untuk menciptakan pembagian kekuasaan yang seimbang dansaling mengecek (checks and balances) antara DPRD dan kepala daerah/wakil kepala daerah. Salah satu ciri pemerintahan yang menganut pembagian kekuasaan yang seimbang dan saling mengecek adalah baik lembaga legislatif maupun eksekutif samasama dipilih secara langsung oleh rakyat melalui pemilihan umum. Keduanya memiliki kekuasaan yang seimbang dengan tugas dan kewenangan yang berbeda, keduanya saling mengontrol melalui pembuatan peraturan daerah dan APBD, keduanya memiliki legitimasi dari rakyat. Dalam bahasa yang sering digunakan oleh elit lokal, kepala daerah dan wakil kepala daerah dipilih secara langsung oleh rakyat melalui pemilihan umum untuk menjamin agar kepala daerah menjadi mitra sejajar dengan DPRD. Dengan begitu interaksi DPRD dan kepala daerah/wakil kepala daerah diharapkan tidak saja dinamis tetapi produktif bagi kesejahteraan masyarakat daerah ${ }^{7}$. Oleh karena itu, sistem politik memiliki peran penting terutama terkait sistem pemilihan langsung baik dalam konteks nasional maupun lokal/daerah.

David Easton dalam Schumann (2003), mengemukakan pendapatnya teoretisi politik pertama yang 
memperkenalkan pendekatan sistem dalam politik, menyatakan bahwa suatu sistem selalu memiliki sekurangnya tiga sifat, yakni terdiri dari banyak bagian, bagian itu saling berinteraksi, saling tergantung dan mempunyai perbatasan yang memisahkan dari lingkungannya yang juga terdiri dari sistem-sistem lain.Sebagai suatu sistem, sistem pemilihan kepala daerah mempunyai bagian-bagian yang merupakan sistem sekunder dan sub-sub sistem. Bagian tersebut adalah, electoral regulation, electoral process, dan electoral law enforcement ${ }^{8}$.

Electoral regulation adalah segala ketentuan atau aturan mengenai pemilihankepala daerah yang berlaku bersifat mengikat dan menjadi pedoman bagi penyelenggara, calon dan pemilih dalam menjalankan peran dan fungsi masing-masing. Electoral process adalah seluruh kegiatan yang terkait secara langsung dengan pemilihan kepala daerah yang merujuk pada ketentuan perundangundangan baik bersifat legal maupun teknikal. Electoral law enforcement adalah penegakan hukum terhadap aturan-aturan pemilihan kepala daerah baik politisi, administrasi atau pidana. Ketiga bagian ini dapat menjadi pedoman untuk melaksanakan proses pemilihan kepala daerah.Sedangkan kalau dari perspektif praktisnya, kepala daerah adalah jabatan politik dan jabatan publik yang bertugas memimpin birokrasi dan menggerakkan jalannya roda pemerintahan yang berfungsi sebagai perlindungan, pelayanan publik, dan pembangunan. Istilah jabatan publik mengandung arti bahwa kepala daerah menjalankan fungsi pengambilan kebijakan yang terkait langsung dengan kepentingan rakyat, berdampak kepada rakyat dan dirasakan oleh rakyat.

Oleh karena itu, kepala daerah harus dipilih oleh rakyat dan wajib mempertanggungjawabkan kepercayaan yang telah diberikan oleh rakyat. Jabatan politik bermakna bahwa mekanisme rekrutmen kepala daerah dilakukan dengan mekanisme politik, yaitu melalui pemilihan yang melibatkan elemen politik, yaitu rakyat dan partai politik ${ }^{9}$.

$$
\text { Pemilihan kepala daerah }
$$

merupakan rekrutmen politik, yaitu penyeleksian rakyat terhadap tokoh-tokoh yang mencalonkan diri sebagai kepala daerah, baik bupati/wakil bupati, bupati/wakil bupati ataupun walikota/wakil walikota. Aktor utama sistem pemilihan kepala daerah adalah rakyat, partai politik dan calon kepala daerah.Dari tinjauan organisasi dan manajemen, kepala daerah merupakan figur atau manajer yang menentukan efektivitas pencapaian tujuan organisasi pemerintahan daerah. Proses pemerintahan di daerah secara sinergis ditentukan sejauh mana peran yang dimainkan oleh 
pemimpin atau manajer pemerintah daerah. Dengan kata lain, arah dan tujuan organisasi pemerintah daerah ditentukan oleh kemampuan, kompetensi, dan kapabilitas kepala daerah dalam melaksanakan fungsi-fungsi administrasi/manajerial, kepemimpinan, pembinaan dan pelayanan, serta tugastugas lain yang menjadi kewajiban dan tanggung jawab kepala daerah.

\section{B. Partisipasi Politik}

Istilah partisipasi politik telah digunakan dalam berbagai arti. Apakah partisipasi politik itu hanya perilaku, atau mencakup pula sikap-sikap dan persepsipersepsi yang merupakan syarat mutlak bagi perilaku partisipasi. Partisipasi politik hanya sebagai kegiatan warga negara yang bertujuan mempengaruhi pengambilan keputusan oleh pemerintah ${ }^{11}$.

Partisipasi politik merupakan aspek penting dalam sebuah tatanan negara demokrasi, sekaligus merupakan ciri khas adanya modernisasi politik. Secara umum dalam masyarakat tradisional yang sifat kepemimpinan politiknya lebih ditentukan oleh segolongan elit penguasa, keterlibatan warga negara dalam ikut serta mempengaruhi pengambilan keputusan, dan mempengaruhi kehidupan bangsa relatif sangat kecil. Warga negara yang hanya terdiri dari masyarakat sederhana cenderung kurang diperhitungkan dalam proses-proses politik.

Di negara-negara yang proses modernisasinya secara umum telah berjalan dengan baik, biasanya tingkat partisipasi warga negara meningkat. Modernisasi dapat berkaitan dengan aspek politik dan pemerintahan seperti adanya modernisasi hukum, administrasi pembangunan, ideologi nasional, pembangunan sosial politik, integrasi politik, pemerataan pembangunan dan partisipasi politik. Dapatlah dikatakan bahwa dengan modernisasi telah menghasilkan partisipasi yang meluas. Partisipasi politik itu merupakan kegiatan yang dilakukan warga negara untuk terlibat dalam proses pengambilan keputusan dengan tujuan untuk mempengaruhi pengambilan keputusan yang dilakukan pemerintah ${ }^{12}$.

Dalam pengertian Budiardjo (1991) partisipasi politik merupakan pengejawantahan dari penyelenggaraan kekuasaan politik yang absah oleh rakyat. Anggota masyarakat yang berpartisipasi dalam proses politik melalui pemilu terdorong oleh keyakinan bahwa melalui kegiatan bersama itu kepentingan mereka akan tersalur atau sekurangnya diperhatikan. Mereka percaya bahwa kegiatan mereka memiliki efek, dan efek tersebut dinamakan political efficacy Dari aspek sosiologi politik, lebih banyak 
rakyat turut berpartisipasi dalam politik menunjukkan bahwa pendidikan politik rakyat berhasil. Partisipasi rakyat yang semakin besar menunjukkan bahwa pelaksanaan demokrasi semakin lebih baik. Tingginya tingkat partisipasi rakyat dimaksud, ditunjukkan oleh banyaknya rakyat mengikuti dan memahami masalah politik dan turut atau ingin melibatkan diri dalam berbagai kegiatan politik.Sebaliknya, jika tingkat partisipasi politik masyarakat rendah, maka menunjukkan indikasi bahwa pelaksanaan demokrasi pada suatu negara kurang baik. Indikasinya, rakyat kurang atau bahkan sama sekali tidak berminat untuk menaruh perhatian terhadap masalah-masalah pemilu dan ketatanegaraan lainnya. Jadi, Kesadaran dan kepercayaan kepada pemerintah (sistem politik) akan mempengaruhi tinggi rendahnya tingkat partisipasi politik mereka dalam kehidupan kenegaraan.

Partisipasi politik, dapat dibagi menjadi partisipasi aktif dan partisipasi pasif. Partisipasi aktif merupakan kegiatan mengajukan usul mengenai suatu kebijakan, mengajukan kritik terhadap suatu kebijakan, membayar pajak, dan memilih pemimpin atau pemerintahan. Partisipasi pasif merupakan kegiatan yang menaati pemerintah, menerima dan melaksanakan apa saja yang diputuskan pemerintah. Selain itu ada model partisipasi selain keduanya, yaitu golongan putih (golput).

Menurut Huntington dan Joan M. Nelson partisipasi dapat terwujud dalam pelbagai bentuk yaitu, pertama, kegiatan pemilihan mencakup memberikan suara, akan tetapi juga sumbangan-sumbangan untuk kampanye, bekerja dalam suatu pemilihan, mencari dukungan bagi seorang calon, atau setiap tindakan yang bertujuan mempengaruhi hasil proses pemilihan. Kedua, lobbying mencakup upaya-upaya perorangan atau kelompok untuk menghubungi pejabat-pejabat pemerintah dan pemimpin-pemimpin politik dengan maksud mempengaruhi keputusankeputusan mereka mengenai persoalanpersoalan yang menyangkut sejumlah besar orang. Ketiga, kegiatan organisasi, menyangkut partisipasi sebagai anggota atau pejabat dalam suatu organisasi yang tujuannya utama dan eksplisit adalah mempengaruhi pengambilan keputusan pemerintah. Keempat, mencari koneksi (contacting) merupakan tindakan perorangan yangditujukan terhadap pejabat-pejabat pemerintah dan biasanya dengan maksud memperoleh manfaat bagi hanya satu orang atau segelintir orang.

\section{Komunikasi Politik}

Untuk memahami komunikasi politik harus diperhatikan pengertianpengertian yang terkandung dalam kedua perkataan tersebut, yaitu komunikasi dan 
politik, baik secara teori maupun penerapannya, dengan melihat kaitan antara komponen yang satu dengan komponen yang lain secara fungsional, di mana terdapat tujuan yang jelas yang akan dicapai. Sanders dan Kaid dalam karyanya, berjudul Political Communication, Theory and Research:An Overview 1976-1977”, mengatakan bahwa komunikasi politik harus intensionally persuasive.

Menurut Rush dan Althoff (1997:255) sebagaimana yang dikutip oleh Asep Saipul Muhtadi (2008: 28), Komunikasi politik adalah transmisi informasi yang relevan secara politis dari satu bagian sistem politik - merupakan unsur dinamis dari suatu sistem politik; dan proses sosialisasi, partisipasi serta rekrutmen politik bergantung pada komunikasi ${ }^{17}$. Secara sederhana unsurunsur tersebut dapat digambarkan sebagai berikut:

\section{Sistem Politik dalam Komunikasi Politik}

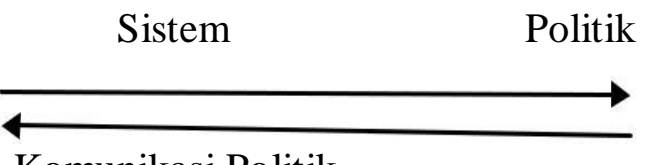

Komunikasi Politik

Komunikasi politik adalah salah satu dari tujuh fungsi yang dijalankan oleh setiap sistem politik. Dalam kata-kata Almond sendiri:

"All of the functions performed in the political system - political socialization and recruitment, interest articulation, interest aggregation, rule making, rule application, and rule adjudication - are performed by means of communication."

Dalam buku The Politics of The Development Areas, pada tahun 1960. Almond berpendapat bahwa komunikasi politik adalah salah satu fungsi yang selalu ada dalam setiap sistem politik sehingga terbuka kemungkinan bagi para ilmuwan politik untuk memperbandingkan berbagai sistem politik dengan latar belakang budaya yang berbeda.

Faktor tujuan dalam komunikasi politik itu, jelas pula tampak pada definisi yang diketengahkan oleh Lord Windlesham dalam karyanya, What is politicalcommunication, Komunikasi politik adalah suatu penyampaian pesan politik yangsecara sengaja dilakukan oleh komunikator kepada komunikan dengan tujuan membuat komunikasi berperilaku tertentu.

Menurut Dan Nimmo komunikasi Politik yaitu (kegiatan) komunikasi yang dianggap komunikasi politik berdasarkan konsekuensi-konsekuensinya (aktual maupun potensial) yang mengatur perbuatan manusia di dalam kondisikondisi konflik. Sementara menurut Michael Schudson (1997: 311) komunikasi politik itu "any transmission of message 
that has, or is intended tohave, an effect on the distribution or use of power in society or an attitude toward the use of power". Gejala komunikasi politik menurutnya bisa dilihat dari duaarah. Pertama, bagaimana institusi-institusi negara yang bersifat formal atau suprastruktur politik menyampaikan pesan-pesan politik kepada publik. Kedua, bagaimana insfrastruktur politik merespons dan mengartikulasikan pesan-pesan politik terhadap suprastruktur $^{21}$.

\section{Strategi Komunikasi Politik}

Strategi komunkasi politik merupakan sebuah taktik yang begitu berperan dalam pemenangan pemilihan umum. Keberhasilan strategi komunikasi politik memberikan sebuah kontribusi yang besar dalam menggunakan dan merencanakan strategi pasangan kandidat atau partai politik untuk menyusun tidak hanya dalam menghadapi pemilu namun juga pasca pemilu. Strategi pada hakekatnya adalah perencanaan (planning) dan manajemen (management) untuk mencapai suatu tujuan. Akan tetapi untuk mencapai tujuan tersebut, strategi tidak berfungsi sebagai peta jalan yang hanya menunjukkan arah saja, melainkan harus mampu menunjukkan bagaimana taktik operasionalnya.

Oleh karena itu, politik dan strategi, kedua hal tersebut harus berjalan beriringan apabila mengejar tujuan berpolitik dalam pemenangan pemilu atau pilkada. Sementara itu strategi juga membutuhkan taktik, prasyaratan dalam sebuah perencanaan taktik adalah adanya perencanaan strategi. Perencanaan taktik dan pengambilan tindakan hanya dapat memiliki arti apabila sebuah strategi direncanakan secara teliti. Jadi perencanaan taktikdapat memberikan jawaban atas pertanyaan siapa, akan melakukan apa, kapan, di mana, bagaimana dan mengapa. Keputusan taktis semacam ini digunakan untuk mencapai setiap tujuan strategis. Keputusankeputusan ini terutama tergantung pada pengenalan akan ruang lingkup, kerangka prasyarat, dan kemampuan pribadi. Oleh karena itu, perencanaan taktis hendaknya tidak direncanakan dari tingkat strategis, melainkan oleh pimpinan yang ada di tingkat taktis, karena hanya di sinilah pengetahuan yang dibutuhkan berada.

Dalam kontek pilkada, strategi komunikasi politik memiliki peran sentral dalam agenda meraih kemenangan. Seorang kandidat dalam hal ini tidak hanya mengandalkan popularitassaja, namun ada strategi komunikasi politik yang bisadiaplikasikan sesuai dengan kondisi dan tempat di mana kontestasi diselenggarakan. Apalagi untuk kandidat yang kurang memiliki popularitas di mata masyarakat, tentu membutuhkan atau mencari strategi komunikasi yang efektif 
untuk mensosialisasikan visi misinya untuk memenangkan pertarungan antar kandidat dalam pilkada.

\section{METODE PENELITIAN}

Penelitian ini merupakan penelitian deskriptif kualitatif. Penggunaan metode kualitatif dalam penelitian tentangstrategi komunikasi politik adalah dikarenakan bukanhanya konseptentang strategi komunikasi sulit, dan mungkin tidak bisa diukur dengan angka-angka, tetapi juga karena strategi komunikasi memiliki penilaian yang bersifat kualitatif. Penilaian kualitatif ini menyangkut persepsi, pendapat, gambaran, pemahaman, pengetahuan seseorang terhadap suatu objek yang nilainya sangat tergantung pada jawaban yang membutuhkan penjelasan mendalam berdasarkan apa yang diketahuinya. Bukan berarti bahwa penelitian tentang strategi komunikasi para perancang strategi tidak menggunakan data-data kuantitatif, melainkan sebelum merancang sebuah strategi komunikasi setiap orang tentunya dituntut untuk mendalami setiap aspek secara mendalam dan menyeluruh. Penelitian kualitatif berusaha menemukan teori, teori substantif atau formal yang kesemuanya jelas berasal dari data ${ }^{23}$.

\section{DISKUSI TEMUAN}

Betapapun fenomena pilkada telah menjadi ikon demokratisasi di Indonesia Pasca Orde Baru. Selain jumlah pemilihan langsung yang sangat banyak dalam satu tahun, pelaksanaan pilkada juga diwarnai isu konflik karena berbagai hal: regulasi, kapasitas penyelenggara, persaingan antar pendukung pasangan calon, konflik internal partai. Pilkada juga menjadi pertarungan antara para (petahana) dalam mempertahankan kekuasaan formalnya untuk periode kedua. Oleh karena itu, ruang demokrasi lokal yang terbuka ini harus dimanfaatkan sebaik-baiknya, pilkada tidak dijadikan ruang konflik politik yang tidak menghasilkan apapun, namun pilkada adalah prosesdemokrasi yang mesti dijalankan dengan penuh harapan guna memilih kepala daerah yang sesuai dengan pilihan rakyat.

Melalui pilkada langsung, rakyat menentukan calon berdasarkan kredibilitas dan kapabilitasnya. Publik daerah melihat rekam jejak dan pengabdian mereka pada daerah itu sendiri. Atas dasar aspek inilah konstituen daerah akan memilihnya. Apabila di era yang transparan ini dengan dukungan media massa, rekam jejak figur dengan mudah dapat dilacak. Bagaimanapun perjalanan proses karir sang kandidat, baik politik, pemerintah maupun karir bisnis akan tergambar dan 
menjadi representasi dari jati diri seorang figur kandidat.

Pilkada Kepahiang 2015 memunculkan tiga pasangan calon yang akan memimpin Kabupaten Kepahiang. Ketiga pasangan calon itu adalah pertama, Ir. Firdaus Djalani dan Bahruddin. Kedua, Dr. Ir. Hidayatullah Sjahid, MM dan Netti Herawati, S.Sos dan ketigaBambang Sugianto, SH, M.Hum dan Arbi, S.IP. Ketiga pasangan calon tersebut merupakan putra-putri daerah yang sudah berpengalaman dalam berorganisasi dan berpengalaman pada bidangnya masingmasing. Mereka, sebagai warga Kepahiang memiliki hak untuk ikut kontestasi dalam Pilkada Kepahiang 2015, dan masyarakat Kepahianglah yang menyeleksi dari ketiga pasangan calon tersebut. Alhasil pada Pilkada Kepahiang yang diselenggarakan pada tanggal 9 Desember 2015 , dimenangkan oleh pasangan calon Hidayatullah Sjahid-Netti Herawati dengan memperoleh 38.568 suara dari daftar pemilih tetap yang berjumlah 70.768 pemilih. Maka pasangan calon Hidayatullah Sjahid dan Netti Herawati yang menjadi Bupati Kepahiang periode 2016-2021.

Menurut data KPU Kabupaten Kepahiang, jumlah daftar pemilih tetap (DPT) mencapai 109.690 pemilih. Sementara partisipasi warga masyarakat Kepahiang yang menggunakan hak pilih/suaranya pada saat Pilkada Kepahiang 2015 sebanyak 70.768 pemilih. Warga Kepahiang yang absen atau tidak menggunakan hak pilihnya sebesar 38.922 suara. Adapun tingkat partisipasi warga masyarakat Kepahiang dalam Pilkada Kepahiang 2015 yaitu:

Jumlah Daftar Pemilih Tetap

\begin{tabular}{|l|c|c|l|c|}
\hline \multirow{2}{*}{} & \multicolumn{3}{|c|}{ JUMLAH PEMILIH } & \multirow{2}{*}{ TPS } \\
\cline { 2 - 4 } & Pria & Wanita & Jumlah & \\
\hline umlah & 56.240 & 53.450 & 109.690 & 293 \\
\hline
\end{tabular}

Sumber: KPU Provinsi Kepahiang

Dari Data KPU Kabupaten Kepahiang menyatakan bahwa Kecamatan Kepahiang mempunyai jumlah terbesar daftar pemilih tetap (DPT) dengan jumlah sebanyak 31.361. Secara keseluruhan daftar pemilih tetap (DPT) antara pemilih laki-laki dan perempuan lebih banyak jumlah pemilih laki-laki sebanyak 56.240, sedangkan jumlah pemilih perempuan sebanyak 53.450. Sementara itu jumlah keseluruhan DPT sebesar 109.690 dan jumlah tempat pemungutan suara (TPS) sebanyak 293.

Pemilihan Bupati dan Wakil Bupati Kabupaten Kepahiang pada tahun 2015, merupakan sebuah proses demokrasi yang menentukan selama 5 tahun. Dengan pilkada itu, memilih pejabat eksekutif yaitu Bupati dan Wakilnya sesuai dengan peraturan Komisi Pemilihan Umum (KPU) 
No. 7 Tahun 2006. Masyarakat sudah diberikan kebebasan untuk menentukan siapa pemimpin yang diyakini bisa menjadikan daerahnya lebih baik.Dinamika politik lokal menjelang Pilbub Kepahiang semakin semarak mendekati hari pemilihan. Hingar-bingar pilkada semakin muncul di permukaan, dengan ditandai berbagai macam manuver politik yang dilakukan oleh setiap pasangan kandidat Pilbub Kepahiang yang diselenggarakan pada tanggal 9 Desember 2015. Adapun pasangan kandidat pada Pilbub Kepahiang 2015 antara lain: nomor urut pertama adalah pasangan pertama, Ir. Firdaus Djalani dan Bahruddin. Kedua, Dr. Ir. Hidayatullah Sjahid, MM dan Netti Herawati, S.Sos dan ketiga Bambang Sugianto, SH, M.Hum dan Arbi, S.IP. Pencalonan pasangan Hidayatullah Sjahid dan Netti Herawati diusung oleh 3 partai politik yang memiliki kursi di DPRD Kabupaten Kepahiang. Partai-partai yang mengusung pasangan Hidayatullah Sjahid dan Netti Herawati antara lain: Partai Nasdem, Partai Hanura, Partai Gerindra.Pencalonan Ratu Hidayatullah Sjahid dan Netti Herawati dalam Pilkada Kepahiang 2015 yang telah didukung oleh partai parlemen dan partai non-parlemen secara umum melewati tiga tahap penting, yaitu, pertama, penjaringan calon. Penjaringan calon ini merupakan demokrasi internal partai yang biasanya harus dilewati oleh anggota partai atau siapapun yang berniat mencalonkan diri menjadi kandidat kepala daerah. Kedua, penyaringan dan seleksi yang telah dijaring. Berdasarkan elektabilitas kandidat di mata masyarakat menjadi aspek yang menentukan calon mana yang akan didukung oleh partai pengusung. Ketiga, penetapan calon. Mencakup interaksi elit partai tingkat kabupaten dengan tim yang dibentuk dengan memperoleh wewenang dari keputusan Dewan Pimpinan Pusat (DPP) Partai Nasdem dan partai pendukung lainnya.Strategi pemenangan pasangan Hidayatullah Sjahid dan Netti Herawati. Sebelumnya juga pernah pelaksana tugas (plt) bupati Provinsi Kepahiang. Sebagai calon yang pernah menjabat, posisi Hidayatullah Sjahid memiliki sejumlah keuntungan dibanding calon-calon lain dalam Pilkada Kepahiang 2015. Selain memiliki investasi politik dalam Pilkada Kepahiang, Hidayatulah Sjahid sebagai calon yang pernah menjabat diuntungkan menggandeng Netti Herawati, yaitu sosok yang memiliki Keluarga popularitas tinggi di mata masyarakat. Dan tentu hal ini juga menjadi kantong suara yang cukup signifikan khususnya di Kecamatan Bermani Ilir dan Muara Kemumu. Agenda Pilkada Kepahiang sebagai proses demokrasi lima tahunan memang sudah selesai diselenggarakan pada 9 Desember 
2015, namun banyak media massa memberitakan soal kecurangankecurangan yang terjadi pada masa pemilihan berlangsung. Maka, pada saat KPU Kepahiang mengumumkan perolehan hasil suara Pilkada Kepahiang pada tanggal 9 Desember, kedua kandidat yaitu pasangan Ir. Firdaus Djalani dan Bahruddin dan Bambang Sugianto, SH, M.Hum dan Arbi, S.IP menggugat pilkada, karena banyak kecurangan yang dilakukan oleh kandidat pemenang, Hidayatulah Sjahid-Netti Herawati. Namun gugatan itu ditolak oleh Mahkamah Konstitusi (MK) karena tidak memiliki bukti yang kuat.

Sementara itu, Komisi Pemilihan Umum (KPU) Kepahiang sudah menetapkan Rekapitulasi Hasil Penghitungan Perolehan Suara Pada Pemilihan Umum Bupati dan Wakil Bupati Kepahiang 2015 bahwa pasangan calon nomor urut pertama yaitu Bambang Dan Arbi memperoleh 25.242 suara atau $38,93 \%$ suara pemilih. Pasangan nomor urut kedua yaitu Hidayatulah Sjahid dan Netti Herawati memperoleh 2.136.035 suara atau $49,61 \%$ pemilih dan pasangan nomor urut ketiga yaitu Firdaus dan Bahruddin memperoleh 10.193 suara atau $11,40 \%$. Perolehan suara di Kecamatan Kepahiang dimenangkan oleh pasangan nomor urut kedua yaitu Hidayatulah Sjahid dan Netti Herawati, kecuali di Ujan Mas dimenangkan oleh pasangan nomor urut satu, Bambang-Arbi.

Dari data-data di atas menggambarkan bahwa hasil Pilkada Kepahiang 2015, pasangan Hidayatullah Sjahid dan Netti Herawati menang, karena konstituen dalam hal ini, pemilih yang menggunakan suara masih mempercayai kandidat terpilih Hidayatulah Sjahid menjadi bupati dan Netti Herawati menjadi wakil bupati yangmendampinginya pada periode 2016 - 2021. Ada implikasi langsung di sana bahwa masyarakat Kepahiang menginginkan Hidayatulah Sjahid menjadi Bupatinya dengan didampingi Netti Herawati sebagai wakilnya. Pasangan ini dianggap mampu membangun Kepahiang menjadi lebih baik.Dalam Pilkada Kepahiang 2015, Hidayatulah Sjahid mencalonkan diri sebagai Bupati Kabupaten Kepahiang periode 2016-2021. Pencalonan Hidayatulah Sjahid ini tentu bukan karena ia pernah menjabat plt saja, namun setidaknya ada tiga hal penting yang dimilikinya, dan ini menjadi strategi komunikasi politik yang efektif. Pertama, Hidayatulah Sjahid mempunyai modal sosial (social capital), modal sosial ini bisa dilihat ia adalah seorang tokoh Kepahiang yang kharismatik,selain itu ia juga orang yang berpendidikan baik, dia juga pernah jadi plt bupati sebelumnya.Kedua, ia memiliki financial yang mendukung, 
karena bagaimanapun sistemdemokrasi yang melahirkan one man one vote menggiring seorang kandidat harus memperoleh suara mayoritas jika ingin menang. Dan untuk menjalankannya, dukungan financial yang memadai nyaris tidak bisa dihindari. Ketiga, network (jaringan), seorang kandidat kepala daerah harus memiliki jaringan yang luas. Jaringan ini terbagi menjadi 2 yaitu pertama, jejaring komunitas, seperti majlis taklim, kelompok petani dan komunitas lainnya. Kedua, jejaring yang sengaja dibentuk. Untuk memenangkan pilkada, Hidayatulah Sjahid menciptakan jejaring misalnya SEHATIyang menjadi organ taktis dari tingkat Kecamatan sampai tingkat Desa, organ taktis ini bisa bekerja secara efektif untuk mendukung pencalonan Hidayatullah sebagai bupati Kepahiang.

Strategi komunikasi politik tim sukses pasangan Hidayatulah Sjahid-Netti Herawati dibuat berdasarkan latar belakang serta analisa-analisa dari hasil situasi pada saat strategi tersebut akan dijalankan. Perumusan strategi komunikasi khususnya pada sebuah kampanye politik akan melalui waktu yang relatif lama, dikarenakan banyaknya pertimbangan sehingga pada akhirnya suatu strategi komunikasi politik diaplikasikan. Dan strategi komunikasi yang efektif adalah yang fleksibel di sini adalah dapat berubah sesuai dengan kebutuhan baik situasi dan kondisi di lapangan.Untuk menghasilkan strategi komunikasi politik yang efektif posisi komunikator juga sangat menjadi bahan pertimbangan penting, karena komunikator dalam hal ini pasangan Hidayatulah Sjahid dan Netti Herawati, keduanya memiliki ketokohan yang sangat diperhitungkan di kalangan masyarakat Kepahiang. Posisi Hidayatulah Sjahid selain pernah menjabat bupati Provinsi Kepahiang, Netti Herawati merupakan seorang Adik dari toko politik popular di Kabupaten. Peran dan rekam jejak sebagai seorang pemimpim akan mempengaruhi persepsi khalayak publik dalam menilainya. Dan ini akan memberikan pengaruh yang besar terhadap terbentuknya opini publik.

\section{PENUTUP}

Strategi komunikasi politik yang dilakukan oleh tim sukses pemenangan pasangan Hidayatullah Sjahid dan Netti Herawati di antaranya adalah: tim sukses partai pengusung dan partai pendukung serta tim sukses relawan. Strategi yang dijalankan oleh tim sukses pendukung pasangan Hidayatullah Sjahid dan Netti Herawati banyak melingkupi pada jaringan organisasinya yang membawahi organisasi kepemudaan, badan sosial dan lainnya. Strategi komunikasi politik lainnya yang dibangun oleh tim sukses partai pengusung 
pasangan dan pendukung lebih bergerak pada sistem organisasional partai dan ketokohan, pada bagian ini diusahakan bekerja secara optimal, terlebih partai pengusung dan partai pendukung masuk kategori partai-partai besar yang diperhitungkan. Strategi komunikasi politik yang dilakukan dengan menyeluruh untuk menggapai segala lapisan masyarakat Kepahiang, ini yang merupakan salah satu faktor penentu atas kemenangan yang diraih oleh pasangan kandidat Hidayatullah Sjahid dan Netti Herawati.

\section{endnote}

${ }^{1}$ Abdullah, Rozali, Pelaksanaan Otonomi Luas dengan Pemilihan Kepala DaerahSecara Langsung, Jakarta: PT Raja Grafindo Persada, 2005.

${ }^{2}$ Andrianus Pito, Toni dkk, Mengenal Teori-Teori Politik, Bandung: Penerbit Nuansa, 2006.

${ }^{3}$ Ardianto, Elvinaro dan Bambang QAnees, Filsafat Ilmu Komunikasi, Bandung: PT Remaja Rosdakarya, 2007.

${ }^{4}$ Arifin, Anwar, Komunikasi Politik, Paradigma, Teori, Aplikasi, Strategikomunikasi Politik di Indonesia, Jakarta: Balai Pustaka, 2006.

${ }^{5}$ Berger, Charles \& Steven Caffee, Handbook of Communication science, USA, SAGE Publication, 1987.

${ }^{6}$ Bungin, Burhan, Penelitian Kualitatif: Komununikasi, Ekonomi, KebijakanPublik, dan Ilmu Sosial lainnya, Jakarta: Kencana Prenada Media Group,2007.

${ }^{7}$ Budiardjo, Miriam, Dasar-Dasar Ilmu Politik, Jakarta: Gramedia, 1991.
${ }^{8}$ Cangara, Hafied, Komunikasi Politik, Konsep, Teori dan Strategi, Jakarta: Raja Grafindo Persada, 2009.

${ }^{9}$ Clymer Rodee, Carton dkk, Pengantar Ilmu Politik, Jakarta: PT Raja Grafindo Persada, 2000.

${ }^{10}$ Leo Agustino, Pilkada dan Dinamika Politik Lokal, Yogyakarta: Pustaka Pelajar. 2009. 